\title{
Basophilic Erythroblast
}

National Cancer Institute

\section{Source}

National Cancer Institute. Basophilic Erythroblast. NCI Thesaurus. Code C13130.

A nucleated red blood cell that stains readily with basic dye. 